genetic system. It is only in favourable cases that the critical evidence emerges which shows that steps in human evolution can occur at a rate much faster than the genetic mechanisms could bring about. Cultural phenomena which involve stability over long periods need not necessarily, on a priori grounds, be attributed to the genetical system; there is no reason to doubt that cultural transmission may operate over many generations. Such questions will only be answerable when we find further methods of gathering empirical data which will enable us to distinguish the contributions of the two informationtransmitting systems in each particular case.
${ }^{1}$ Bateson, W., "Mendel's Principles of Heredity" (Cambridge University'Press, 1909).

${ }^{2}$ Darlington, C. D., "The Evolution of Genetic Systems" (Cambridge University Press, 1939).

"Waddington, C. H., "The Strategy of the Genes" (Allen and Unwin, London, 1957).

"Waddington,! C.' H., Evolution, 10, 1 (1957); J. Genet., 55, 241 (1956).

"Darlington, C. D., "The Control of Evolution in Man" (Woodhull Lecture). Proc.' Roy. Inst. Vol. 37 ; Nature, 18214 (1958); see also "The Facts of Life" (Allen and Unwin, London, 1053).

- Waddington, C. H., "The Human Evolutionary System". Proc. addington, C. H., "The Human Evolutionary System"; Proc.
Conference on Darwin and Sociology, Edinburgh, April, 1959 Conference on
(in the press).

"Mead, Margaret, "New Lives for Old" (Gollanez, London, 1956).

s Lerner, I. M., "Genetic Homeostasis" (Oliver and Boyd, Edinburgh, 1954).

\title{
OBITUARIES
}

Sir Stanley Angwin, K.C.M.G., K.B.E., D.S.O., M.C.

THE death on April 21 at the age of seventy-five of Sir Stanley Angwin brings to a close a remarkable military and engineering career. Educated at Queen Mary College, he received his practical training with Messrs. Yarrow and Co., the shipbuilders. In 1906, at the age of twenty-three, he entered the Engineering Department of the Post Office, a step which took him in the course of fifty years to the highest engineering and administrative positions in the telecommunications field; he became engineer-in-chief of the Post Office in 1939, chairman of Cable and Wireless in 1947 and finally chairman of the Common. wealth Telecommunications Board from 1951 until 1956.

It was provident that Angwin was engineer-inchief during the Second World War, for the part played by telecommunications was vital and demanded extreme co-operation with the Fighting Services. Angwin had a foot in both the Civil and Services' camps, for he had been associated with the Army Signals since the inauguration of the Territorial Army. His Unit, which he raised as the Lowland Division Telegraph Company, was mobilized in 1914 to form the 52nd Divisional Signal Company and served throughout the First World War in Gallipoli, Egypt, Palestine and France. He was awarded the D.S.O. and M.C., and those who knew his scant personal regard for air raids in 1940 can readily imagine the value and influence of his imperturbable personality as a young commander in the earlier War. His association with Army Signals continued between the Wars, first in command of the 44th Home Counties Divisional Signals and finally as deputy chief signal officer for the Supplementary Reserve.

With this background, Angwin was in an excellent and accepted position to assess and direct the provision of the many long-distance circuits and installations required for the defence of the United Kingdom. The demands for Post Office services were overwhelming, and sometimes competing, particularly for air defence, and later for the U.S. Armed Forces, and the preparations for $D$ Day. All this in the face of bomb damage, and incessant repairs, provided a formidable task of direction, while at the same time Angwin fostered the release of technical staff to the Forces for the build-up of the signal staffs and units overseas whero their professional knowledge was indispensable.

Between the Wars Angwin's work had been associated with the development of the Post Office and Commonwealth radio services. On his return from the First World War he was appointed to the wireless section of the Engineer-in-Chief's office. There he found, in an era of development, just those opportunities needed to match his many talents. On the technical side he found scope for applying his knowledge and experience in the design and construction of high-power radio stations at Cairo, Leafield and Rugby; and was closely connected with the establishment in 1927 of the first transAtlantic telephone service and in the subsequent development of short-wave radio telephone services to all parts of the world.

Angwin's ability in negotiation was equally outstanding. This frequently led to his appointment as chairman of committees, particularly those dealing with controversial matters, at many international telecommunication conferences.

$\mathrm{He}$ was chairman of the Radio Research Board during 1947-52. In 1945 he accompanied Lord Reith on a mission to the members of the Commonwealth to discuss changes in Commonwealth communications, leading to the nationalization of Cable and Wireless, Ltd., and to the setting up of the Commonwealth Telecommunications Board.

On retirement from the Post Office, Angwin became in January 1947 the first chairman of Cable and Wireless, Ltd., in its new role, and in April 1951, at the invitation of the partner Governments, followed Lord Reith as chairman of the Commonwealth Telecommunications Board. In 1950, as chief technical adviser to the Board, he had presided over a meeting of technical and traffic experts from all parts of the Commonwealth, which was the first Commonwealth gathering of its kind. He was chairman of the Board for five years, filling this office with his usual distinction and doing much to further Commonwealth co-operation in all spheres of telecommunications. In 1954 he headed a delegation of the Board to Australia and New Zealand. In 1955 he presided over a second successful technical and traffic conference in London, but in 1956, owing to ill-health, he felt obliged to retire.

As engineer-in-chief of the Post Office, Angwin was knighted in 1941 and made K.B.E. in 1945 for his war services. For his services to international telecommunications he was made K.C.M.G. in 1957. $\mathrm{H}_{\Theta}$ was president of the Institution of Electrical Engineers during 1943-44, Faraday Medallist in 1953 and made an honorary member in 1956. He became a Fellow of Queen Mary College, London, in 1946 
and received an honorary degree of doctor of science from the University of London in 1953.

Lady Angwin was an ideal support to him throughout his career. With their family they made their home in Welwyn Garden City, where his charming house and garden must have been a welcome haven in the midst of his exacting duties.

His friends will remember his quiet and seemingly casual manner, his kindly disposition and yet the confidence he could inspire and the force of his leadership. Gordon Radley

\section{Mr. L. E. Harris}

Mr. LAWRENCE ERNeST HARRIS, a leading authority on fen drainage, died on April 5 at Cambridge, aged sixty-six. The Newcomen Society for the Study of the History of Engineering and Technology has suffered a very severe loss by his unexpected death during his second year as president.

After leaving Mercers School, London, Harris studied at the City and Guilds Engineering College, South Kensington, during 1910-12 and won a Mitchell scholarship. $\mathrm{He}_{\mathrm{e}}$ obtained his practical training with C. Isler and Co., London, artesian well engineers. During the First World War he served in the Royal Fusiliers and the Machine Gun Corps and, as a lieutenant, was invalided out due to war wounds. Having taken a refresher course at King's College, London, Harris joined Sulzer Bros., Ltd., as an estimating engineer in their London office. After three months at their Winterthur Works, he went to India in 1923 as the firm's manager, and for thirteen years was responsible for the sale and installation of many Sulzer steam and diesel engines, pumps and electrical machines in pumping and power stations. Returning to England, he was appointed district manager and engineer for the Sulzer organization in the Fen area in 1937, specializing in fen drainage and pumping machinery. He also installed Sulzer pumps for the Somerset River Board's drainage schemes. He lived in Leeds until 1947, and then in Histon, Cambridge, holding the same appointment until his death.

Harris was intensely interested in the history of his subject, and his authoritative book, "Vermuyden and the Fens", was published in 1953. He wrote the chapter, "Land Drainage and Reclamation" in Vol. 3 of "A History of Technology", published in 1957, and contributed to the Newcomen Society "Sir Cornelis Vermuyden, an Evaluation and an Appreciation" and "Some Factors in the Early Development of the Centrifugal Pump, 1689-1851". In his presidential address, "A Neglected Genius of Seventeenth Century Technology", he paid honour to the inventor, Cornelius Drebbel (1572-1633), of Alkmaar. One of Harris's last interests was to ensure that the beam engine and scoop-wheel installed in 1831 at Stretham, near Ely, by the Butterley Company, should be permanently preserved, as it is the last surviving example of the introduction of steam power for fen drainage. The formation of the Stretham Engine Preservation Trust in 1958 was due to him; he was elected the first chairman of the Trustees and wrote the appeal this year for an endowment fund. His many friends hope the appeal will succeed in its object and that it will be a permanent tribute to his memory. He is survived by his widow, Mrs. Kathleen Harris, and his two sons, Michael and John, both engineers.
A. Stowers

\section{NEWS and VIEWS}

Special Assistant for Science and Technology to the U.S. President: Prof. G. B. Kistiakowsky

Prof. George B. Kistiakowsky, a distinguished physical chemist, who succeeds Dr. James R. Killian (Nature, 181, 384; 1957) as special assistant for science and technology to the President of the United States, spent four years at Princeton University after receiving the Dr.Phil. in Berlin in 1925. He went to Harvard University in 1930, progressing quickly to a professorship in 1937, which he has held ever since. Following early researches on the ultraviolet spectra of polyatomic molecules, and on thermodynamics, after the Second World War he applied shock and detonation waves to the study of chemical problems, determining the heat of dissociation of nitrogen; and employed soft X-rays and mass spectrometers to investigate the phenomena occurring in shock fronts. His most recent studies have been in classical chemical kinetics. Honours that have been accorded to him include the American Medal for Merit (1946), the British Medal for Service in the Cause of Freedom (1948), and the Nichols Medal of the American Chemical Society (1947).

As a civilian scientist during the war years, Prof. Kistiakowsky headed the explosives division of the Manhattan Project, was consultant to the Office of Scientific Research and Development, and adviser to the United States Army on scientific problems of a military character. His wide experience and ability have been recognized by his election to membership in the Philosophical Society and the National Academy of Sciences. In recent years, as a member of the President's Scientific Advisory Committee, his activities and interests have been focused on national scientific policy and on science as a force and a balance in international affairs.

\section{Metallurgy at Manchester: Prof. F. C. Thompson}

Prof. Frank Charles Thompson, who is to retire from the chair of metallurgy and directorship of the Metallurgical Laboratories of the University of Manchester on September 30, will then have served on the Senate of the University for thirty-eight years. Prof. Thompson graduated in the University of Sheffield in 1911 and was awarded the Mappin Medal ; he then served on the staff of the University of Sheffield until 1919, after which he held the Royal Society Sorby Research Fellowship at Sheffield for one year before being called to the chair at Manchester.

At Manchester, Prof. Thompson rapidly established himself as a bold leader of research in his own special subject of the plastic deformation of metals and gave detailed consideration to the atomistics of plastic flow at a time when few physicists realized that a meaningful problem existed in this field of study. $\mathrm{He}$ also, and perhaps in the long run this is more important, established himself as a wise academic statesman and a truly sympathetic 'father' to his department. It was a paternity which protected and encouraged the younger members of his staff while 